\title{
AISを用いた津波漂流船舶の挙動と 衝突被害分析
}

\author{
松田 信彦 ${ }^{1}$ ・富田 孝史 ${ }^{2}$ \\ 1正会員 東亜建設工業株式会社 技術研究開発センター（†230-0035 神奈川県横浜市鶴見区安善町 1-3） \\ E-mail: n_matsuda@toa-const.co.jp \\ 2正会員 国立研究開発法人 港湾空港技術研究所 海洋情報・津波研究領域 \\ （テ239-0826 神奈川県横須賀市長瀬 3-1-1） \\ E-mail: tomita@pari.go.jp
}

\begin{abstract}
一定条件の船舶はAIS の搭載義務があり位置等の情報を無線で自動的に発信し, 近くの船舶や陸上局で 認識されている，本研究は東日本大震災時に鹿島港の陸上局で保存されたAIS データを分析して, 船舶の 津波による漂流挙動と漂流船舶による港湾施設一の衝突の関係を検討し，次のことを明らかにした。(1) 船舶が大型であるほど地震から長時間経過しても衝突被害が発生する。(2) 水路状港湾の奥部では, 反射 波の影響で津波の流れが遅くなることから，継続時間の長い津波であっても漂流距離は短くなり，さらに 速い速度で衝突する可能性が低くなるので, 被害の甚大化が軽減される。(3) 水路状港湾であっても, 津 波の押し引きの転換時を含めた津波流れの複雑性や操船と言う人為的要因によって, 船舶は津波にのって 漂流するだけでなく，斜めや横向きの漂流や回転も発生する.
\end{abstract}

Key Words : tsunami, Automatic Identification System, collision, port facility damage

\section{1. はじめに}

東日本大震災では港内に係留していた大型船舶の多く が津波により漂流し，港湾施設に甚大な被害を与えた. 港湾施設の被害は施設の直接的な被害だけでなく，物流 やエネルギー供給など周辺の産業活動にも長期間にわた り影響することから，大型船舶の津波対策を検討するこ とは重要である.

大型船舶の衝突に関する従来の研究には，岩井ら ${ }^{1)} の$ 船舶の橋脚衝突時の衝突力に関する研究や，上田ら ${ }^{2)} の$ 係留施設の防衝工の設計に関する研究などがある。しか し，実際の漂流船舶の衝突被害については，漂流中の衝 突判定が困難であることから，ほとんど行われていない のが現状である.

船舶航行の安全性向上を目的に，国際航海に従事する 総トン数300 GT 以上の船舶, 国際航海に従事する全て の旅客船，および国際航海に従事しない総トン数500 GT 以上の船舶に船舶自動識別装置（AIS ）の搭載が2008 年 に義務化された. AIS は, 船名, 船の長さ・幅, 船の種 類，船の喫水，位置，速度，針路，船首方向，回頭率な どの情報をVHF 帯電波により定期的に自動送信するシ
ステムである．このような船舶の航海情報が東日本大震 災では記録されている。

本研究では，東日本大震災における被害から逃れた唯 一の基地局である鹿島港のAIS データを分析し，津波に より漂流した船舶の挙動とそれらによる港湾施設への衝 突被害の関係を明らかにすることを目的とした。

\section{2. 津波来襲時の鹿島港}

\section{（1）鹿島港の津波}

鹿島港は茨城県の南東部に位置し，鉄鋼業，発電所， 石油化学等の工場がある鹿島臨海工業地帯に接する掘り 込み港湾である。鹿島港における潮位観測データは験潮 所が被災したため残っていないが，高橋ら゙による津波 痕跡調査によると, 北公共埠頭で浸水高4.71 m, 南公共 埠頭で浸水高6.82 $\mathrm{m}$ である。 また，津波第1波の到達時 刻は，鹿島海上保安署によると，午後3 時32 分頃とされ ている．津金帛によると，地震による摇れは港内に係留 した船上でも大きな摇れとして感じており，係留船舶の 多くは地震直後にテレビなどで津波情報を入手している. 


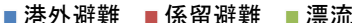

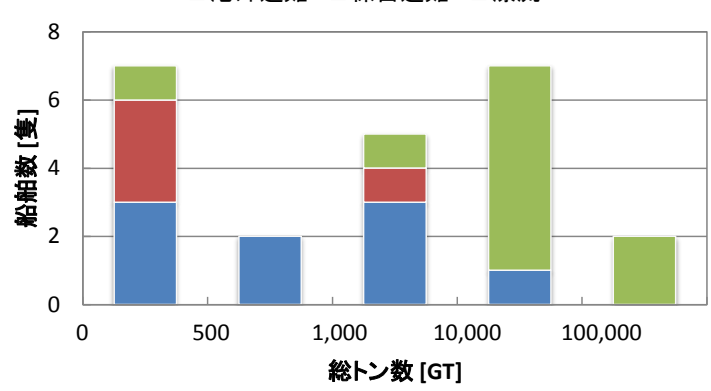

図-1大型船舶の総トン数別津波避難行動

\section{（2）港内船舶の避難状況}

図-1 は地震発生時に港内でAIS を搭載して係留してい た総トン数190 GT 以上の船舶の津波避難行動をAIS デー タから分析した結果である 位置は図-2 に船形の記号で示した。ここで，港外避難 は津波襲来前あるいは襲来中に港外に避難できた船舶, 係留船舶は係留により漂流等の被害を免れた船舶，およ び漂流は津波によって漂流した船舶を示している．分析 した船舶数は23 隻であり，そのうちの13 隻が港外避難 または係留避難を実施できたが，残りの10 隻は港内を 漂流している．特に，総トン数が 1 万GT を超える大型 船舶のほとんど（9 隻中8 隻) が避難することができず に漂流している．また， 1 万GT 未満の船舶でも 2 隻が漂 流しているが，これらは船員が陸上の避難所へ避難した 無人の船舶であった.

大型船舶のほとんどが漂流した原因には，大型船が離

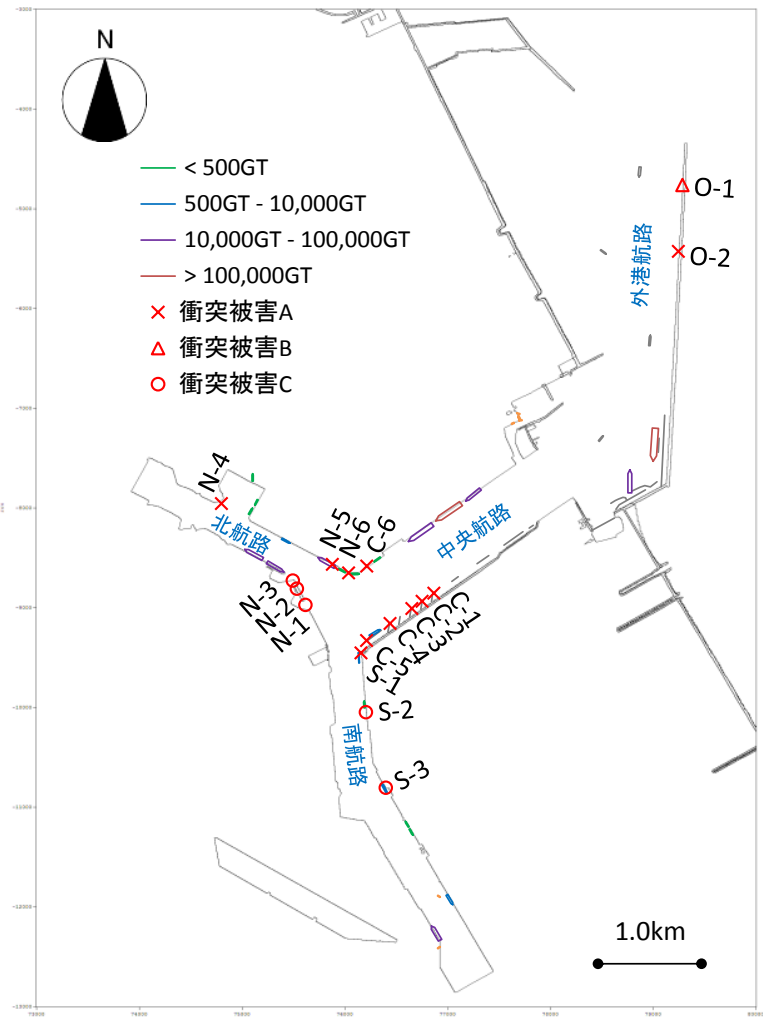

図-2 地震発生時の船舶係留状況と衝突被害場所
栈する際にタグボートが必要であるため，緊急離栈が難 しいという運用上の課題により津波襲来前の避難が困難 であったこと，さらに船舶の水中投影面積が大きいため に津波の作用力が増大するという物理的な課題により係 留避難が困難であったことが推察される。このことから， 大型船舶の漂流被害を軽減させるためには，船舶単独で の緊急離栈の方法（例えば，タグボートの代わりに船首 側の係留索を残すことによって離栈する操船方法等）や その訓練の実施等がソフト対策としてあげられる。また， 小名浜港では防波堤の背後水域に係留していた船舶が係 留避難に成功している事例があり，防波堤や埠頭の配置 により港全体あるいは埠頭等における津波の水位や流速 を低減させるハード整備も対策と考え得る.

\section{3. 船舶衝突時の挙動}

\section{(1) 分析方法}

衝突被害の分析には，地震発生から翌日午前0 時まで の約9 時間のAIS データのうち船舶の位置情報（緯度, 経度），船首方向，船の長さ・船の幅のデータを使用し た。これらデータに基づいて作成した船舶モデルを Google Earth Pro 上の地図データにマッピングして，岸壁 等への衝突を地図上で判定した. さらに，震災直後に鹿 島港内で撮影された被害写真を用いて被害を確認した. ただし，Google Earth Pro のマッピング精度に加え，AIS のGPS 測位精度が10 m 以上の船舶も含まれていること から，衝突判定の精度は必ずしも高精度とは言えない可 能性は残されている.

\section{(2) 大型船舶の衝突パターン}

漂流船舶の衝突パターンの模式図を図-3 に示す。困 中の(1) と(2) は岸壁との衝突で，(3) と(4) は栈橋との衝突 である. Vs はAIS データに基づく船舶の漂流方向である.

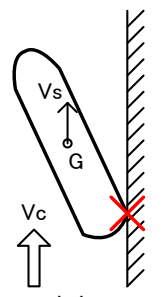

(1)

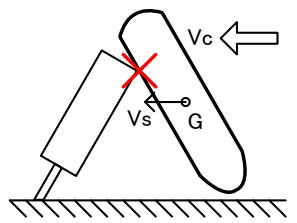

(3)

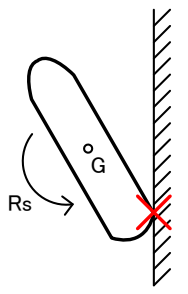

(2)

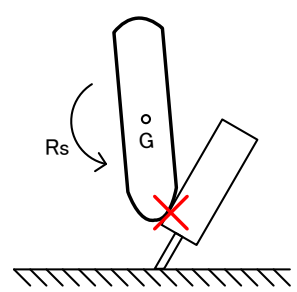

(4) 図-3＼cjkstart漂流船舶の衝突パターン 
Vc は津波による流れの向きを示しているが，実際の流 速データは観測されていないために，ここでは津波によ る流れは航路あるいは岸壁に沿って存在し，その向きは 船舶の移動する向きと同じであると仮定した．G は船の 重心であり，Rs は船舶の回頭角速度である．×印は船 舶が港湾施設と衝突した個所である.

船舶の漂流状況は, 漂流タイプとして流れにのって漂 流するタイプと回転するタイプに大別され，さらに流れ にのって漂流寸るタイプは，流れに対する船首方向の角

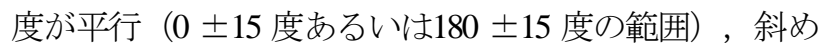

（15～75 度あるいは195 ２55 度の範囲）および横（90 \pm 15 度あるいは 270 度 \pm 15 の範囲）の3 種類に分類した。 寸なわち，漂流タイプを 4 種類に分類した. この分類に 基づいて，漂流船舶衝突時の漂流タイプを航路別に整理 したものを図-4 に示す．また，船舶の衝突箇所を船首， 船尾，船側および乗揚げの 4 種類に分類して航路別に整 理したものを図-5に示す，係留船舶のほとんどは航路 に沿った向きで係留されていたが, 衝突時の漂流タイプ は必ずしも流れに沿った平行漂流だけでなく, 中央航路 では斜め漂流，北航路では回転漂流が多い，各漂流船舶 の挙動をAIS データにより再現してみると, 漂流の途中 では横漂流になる船も少なくなかった。これは，津波に よる押し引きの転換時を含めて津波による流れの複雑性 に加え，操船という人為的な要因もあるため, 幅の狭い 航路内の津波による現象と言えども漂流船舶の挙動は複 雑であることに起因している，ただし，横漂流のまま衝

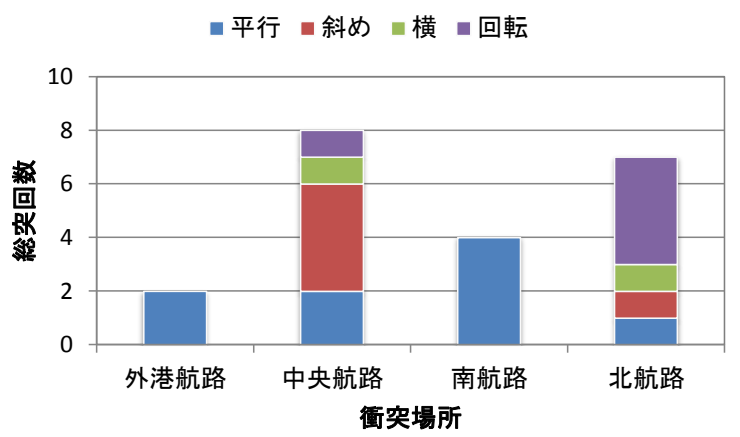

図-4 衝突船舶の漂流タイプ

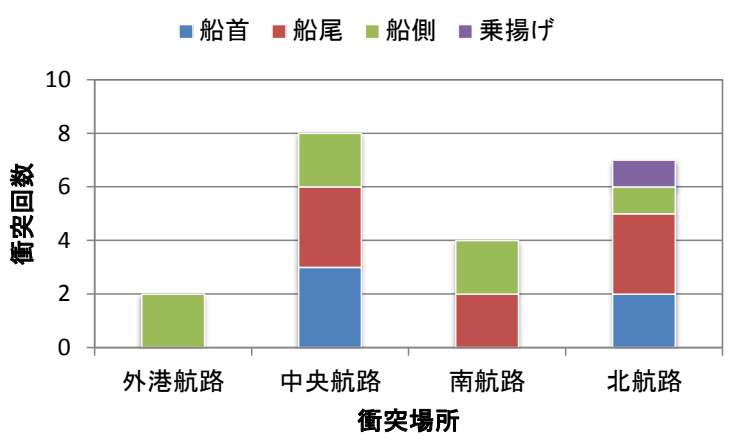

図-5 衝突船舶の衝突箅所
10,000GT以下 10,000-100,000GT 100,000GT以上

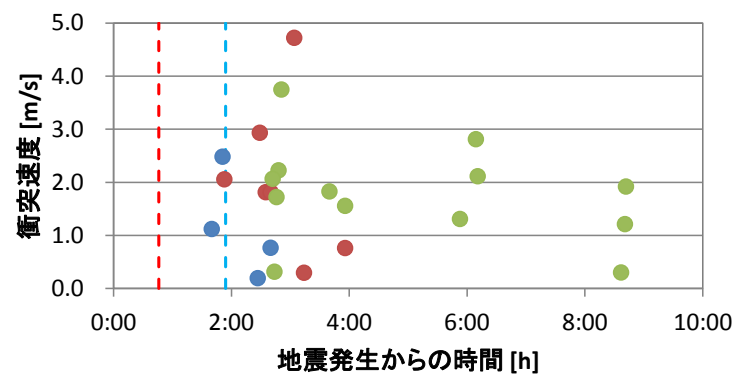

図-6 漂流船舶の衝突速度変化

-10,000GT以下 10,000-100,000GT 100,000GT以上

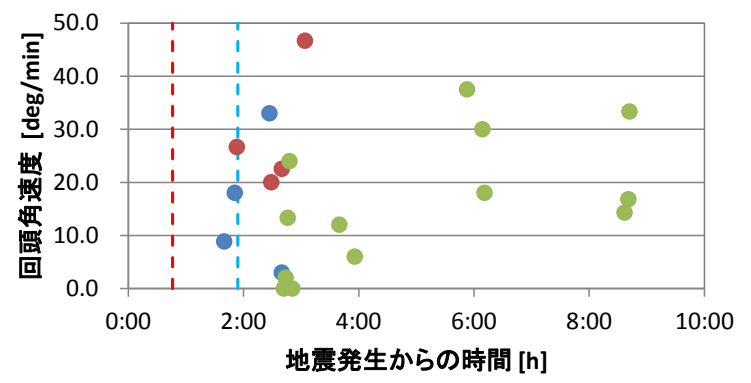

図-7＼cjkstart漂流船舶の衝突時の回頭角速度変化

突する事例は少なく, 中央航路に突き出した栈橋に横漂 流途中に船側から衝突する事例と，北航路の船溜まりで 埠頭に乗り上げた事例のみであった。 このように衝突時 の漂流タイプは様々であるが，船舶における衝突箇所は 船首と船尾が多い.

図-6は漂流した7隻の船舶（図-1参照）の衝突被害場 所での衝突速度変化を総トン数別に示したものである. 図中の赤色および青色の破線は，それぞれ鹿島海上保安 署による津波の第1 波および第2 波の到達時刻である. 図より, 漂流船舶の衝突は第2 波の到達直前に始まって いることが分る．また，船舶が大型であるほど地震発生 から長く時間が経っても衝突被害が発生しており, 総卜 ン数10 万GT 以上の大型船舶の場合には, 地震発生から 9 時間経過しても最大 $2.0 \mathrm{~m} / \mathrm{s}$ 近くの速度で港湾施設に衝 突している．最大衝突速度は時間と共に低下寸る傾向に あるが，船舶重量が大きいために衝突時に被害にまで至 ったと考えられる，そのため船舶が大きいほど衝突被害 が長時間継続する危険性があることが示唆される.

図-7 は衝突被害場所での回頭角速度変化について総 トン数別に示したものである．衝突速度の場合と同様に， 総トン数 10 万GT 以上の船舶では, 地震発生から 9 時間 経過しても, 最大 $33 \mathrm{deg} / \mathrm{min}$ の回頭角速度で衝突してお り，危険な状態が続いていたことが明らかになった。

\section{(3) 衝突事例}

ここでは，流れに対する船首尾方向の角度が漂流速度 に大きく影響する事例を示す．図-8 は，総トン数 91,178 GT の漂流船舶が栈橋C-1 に衝突した時の漂流速度と回 


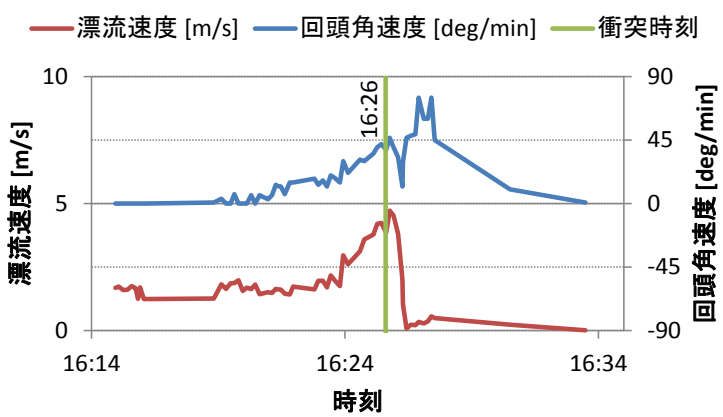

図-8＼cjkstart栈橋衝突時の回頭角速度変化

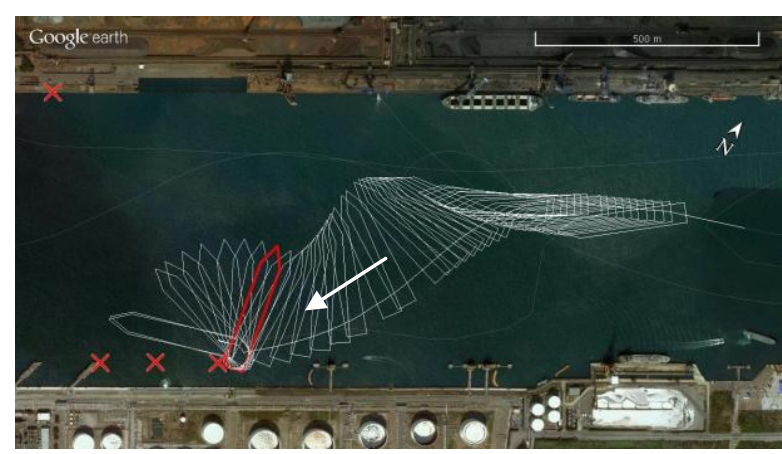

図-9＼cjkstart漂流船舶の航跡

頭角速度の時間変化を示したものである．なお，これら の速度は船に設置されたGPS アンテナの位置でのもので ある. 図中の緑線は衝突時刻16:26 である. 図-8 と同時 刻の航跡および船の向きを地図上に示したものが図-9 である．ただし，AIS データの送信間隔は速力によって 変動するため, 航跡は一定の時間間隔ではない，漂流船
舶は右（港外側）から左（港内側）一向かって漂流し， 赤色で示した位置で時刻16:26に栈橋と衝突している.

図-9 の衝突前の航跡を見ると，16:22 までは水路に沿っ た流れによる船首を前にして平行漂流しているが，何か のきっかけで16:23 に船尾が航路直角方向に回転したこ とにともなって横漂流になり，作用面積の増大にともな った作用流体力の増大により増加した漂流速度で船尾が 栈橋に衝突している．衝突後は急激に漂流速度が低下し， 船首を航路平行方向に回転して動きが止まっている.

\section{4. 施設の被害}

漂流船舶の衝突による港湾施設の被害は，防波堤，岸 壁および栈橋において発生しており合計17 箇所である. 特に南北航路と中央航路が交わるところで被害が多く, そのなかでも中央航路に面する栈橋（C-1〜C-6）およ び北航路（N-5，N-6）において被害が大きい，また， 漂流船舶の衝突被害は，荷役機械にも及んでいる，岸壁 クレーンの倒壊をはじめ，荷揚げ中のアンローダーが津 波で流された原料船に引きちぎられて破損している.

表-1 は漂流船舶の衝突による港湾施設の全ての被害 と衝突時の船舶挙動を整理したものである．表中の衝突 位置は図-2 と対応しており, 衝突角度は防波堤や岸壁 の法線と船首尾方向の角度である．施設状態は施設の損 傷の程度を示しており，その程度を示寸 $\mathrm{A} \sim \mathrm{C}$ は港湾の 施設の維持管理技術マニュアルのに基づいて, 震災直後

表-1＼cjkstart港湾施設の被害と漂流船舶の挙動

\begin{tabular}{|c|c|c|c|c|c|c|c|c|c|c|}
\hline $\begin{array}{l}\text { 衝突 } \\
\text { 位置 }\end{array}$ & 施設 & 損傷程度 & $\begin{array}{l}\text { 施設 } \\
\text { 状態 }\end{array}$ & $\begin{array}{c}\text { 総トン数 } \\
{[\mathrm{GT}]}\end{array}$ & $\begin{array}{c}\text { 地震から } \\
\text { の時間 }\end{array}$ & $\begin{array}{l}\text { 漂流 } \\
\text { タイプ }\end{array}$ & $\begin{array}{l}\text { 衝突 } \\
\text { 場所 }\end{array}$ & $\begin{array}{c}\text { 衝突速度 } \\
{[\mathrm{m} / \mathrm{s}]}\end{array}$ & $\begin{array}{c}\text { 回頭 } \\
\text { 角速度 } \\
\text { [deg/min] }\end{array}$ & $\begin{array}{l}\text { 衝突 } \\
\text { 角度 } \\
\text { [deg] }\end{array}$ \\
\hline $\mathrm{O}-1$ & 防波堤 & 上部工欠損 & $\mathrm{B}$ & 160,066 & $2: 51$ & 平行 & 船側 & 3.7 & 0.0 & 3.0 \\
\hline $\mathrm{O}-2$ & 防波堤 & 上部工大きく欠損 & A & 160,066 & $2: 44$ & 平行 & 船側 & 0.3 & 2.0 & 3.0 \\
\hline \multirow{4}{*}{$\mathrm{C}-1$} & \multirow{4}{*}{ 栈橋 } & \multirow{4}{*}{ 栈橋の半分倒壊 } & \multirow{4}{*}{ A } & 499 & $3: 04$ & 斜め & 船側 & 1.1 & 8.9 & - \\
\hline & & & & 91,178 & $1: 40$ & 斜め & 船尾 & 4.7 & 46.7 & - \\
\hline & & & & 47,027 & $2: 35$ & 不明 & 不明 & 1.8 & NA & - \\
\hline & & & & 47,027 & $3: 56$ & 不明 & 不明 & 0.8 & NA & - \\
\hline $\mathrm{C}-2$ & 栈橋 & 上部工損傷 & $\mathrm{A}$ & 47,027 & $3: 14$ & 不明 & 不明 & 0.3 & NA & - \\
\hline \multirow{2}{*}{$\mathrm{C}-3$} & \multirow{2}{*}{ 栈橋 } & \multirow{2}{*}{ 杭と上部工が損傷 } & \multirow{2}{*}{ A } & 499 & $2: 27$ & 回転 & 船首 & 0.2 & 33.0 & - \\
\hline & & & & 499 & $2: 40$ & 横 & 船側 & 0.8 & 3.0 & - \\
\hline C-4 & 栈橋 & 杭と上部工が損傷 & $\mathrm{A}$ & 106,333 & $3: 56$ & 平行 & 船尾 & 1.6 & 6.0 & - \\
\hline \multirow{2}{*}{$\mathrm{C}-5$} & \multirow{2}{*}{ 栈橋 } & \multirow{2}{*}{ 一部が完全に倒壊 } & \multirow{2}{*}{ A } & 91,178 & $2: 29$ & 斜め & 船首 & 2.9 & 20.0 & - \\
\hline & & & & 106,333 & $2: 48$ & 平行 & 船首 & 2.2 & 24.0 & - \\
\hline $\mathrm{C}-6$ & 岸壁 & 上部工欠損, 防舷材落下 & A & 106,333 & $6: 11$ & 斜め & 船尾 & 2.1 & 18.0 & 33.0 \\
\hline S-1 & 矢板岸壁 & コンクリート欠損 & $\mathrm{A}$ & 106,333 & $2: 46$ & 平行 & 船側 & 1.7 & 13.3 & - \\
\hline \multirow{2}{*}{ S-2 } & \multirow{2}{*}{ 矢板岸壁 } & \multirow{2}{*}{ 上部工コンクリート剥離 } & \multirow{2}{*}{$\mathrm{C}$} & 106,333 & $2: 42$ & 平行 & 船側 & 2.1 & 0.0 & 5.0 \\
\hline & & & & 106,333 & $3: 40$ & 平行 & 船尾 & 1.8 & 12.0 & 7.0 \\
\hline S-3 & 矢板護岸 & 上部工コンクリート剥離 & $\mathrm{C}$ & 5,988 & $1: 51$ & 平行 & 船尾 & 2.5 & 18.0 & - \\
\hline $\mathrm{N}-1$ & 横栈橋 & 上部工コンクリート剥離 & $\mathrm{C}$ & 106,333 & $8: 37$ & 斜め & 船尾 & 0.3 & 14.3 & - \\
\hline $\mathrm{N}-2$ & 横栈橋 & 上部工コンクリート剥離 & $\mathrm{C}$ & 106,333 & $8: 41$ & 回転 & 船尾 & 1.2 & 16.8 & 65.0 \\
\hline $\mathrm{N}-3$ & 横栈橋 & 上部工コンクリート剥離 & $\mathrm{C}$ & 106,333 & $8: 42$ & 回転 & 船尾 & 1.9 & 33.3 & 78.0 \\
\hline $\mathrm{N}-4$ & 矢板護岸 & 矢板変形 & $\mathrm{A}$ & 36,008 & $1: 53$ & 横 & 乗揚げ & 2.1 & 26.7 & - \\
\hline $\mathrm{N}-5$ & 矢板岸壁 & 上部工欠損, 防舷材落下 & $\mathrm{A}$ & 106,333 & $5: 53$ & 回転 & 船首 & 1.3 & 37.5 & 73.0 \\
\hline \multirow{2}{*}{$\mathrm{N}-6$} & \multirow{2}{*}{ 矢板岸壁 } & \multirow{2}{*}{ 上部工欠損, 防舷材落下 } & \multirow{2}{*}{ A } & 91,178 & $2: 40$ & 回転 & 船首 & 1.8 & 22.5 & - \\
\hline & & & & 106,333 & 6:09 & 平行 & 船側 & 2.8 & 30.0 & - \\
\hline
\end{tabular}


表-2 施設の性能評価分類

\begin{tabular}{c|l}
\hline 評価 & \multicolumn{1}{|c}{ 施設の状態 } \\
\hline $\mathrm{A}$ & 施設の性能が低下している状態 \\
\hline $\mathrm{B}$ & $\begin{array}{l}\text { 放置した場合に, 施設の性能が低下する恐れが } \\
\text { ある状態 }\end{array}$ \\
\hline $\mathrm{C}$ & $\begin{array}{l}\text { 施設の性能にかかわる変化は認められないが, } \\
\text { 継続して観察する必要がある状態 }\end{array}$ \\
\hline $\mathrm{D}$ & $\begin{array}{l}\text { 異状は認められず, 十分な性能を保持している } \\
\text { 状態 }\end{array}$ \\
\hline
\end{tabular}

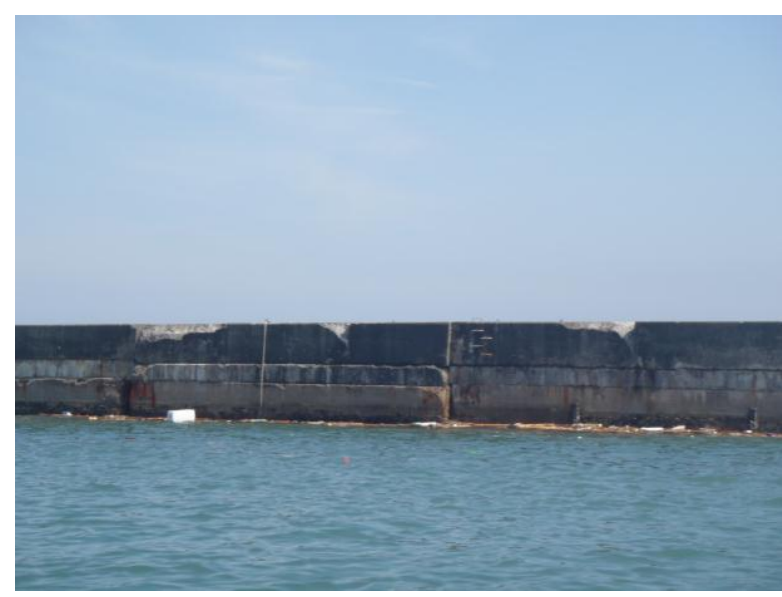

写真-1＼cjkstart防波堤(O-1)の衝突被害状況

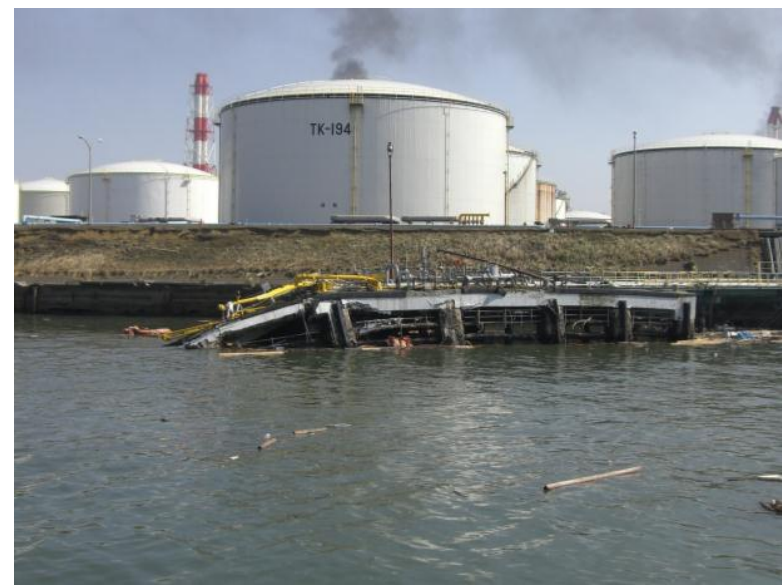

写真-2 栈橋(C-1)の衝突被害状況

の被害写真から表-2 の施設の性能評価分類を用いて評 価した。例えば，写真-1 は位置O-1 における被害程度B の防波堤である. ここでは上部工が久損している. 写真 -2 は位置C-1 における被害程度Aの栈橋である。ここで は漂流船舶が何度も衝突して施設の半分が倒壊している。 写真-3 は位置N-3 における被害程度C の岸壁である。こ こでは上部工の一部が剥離しているが，防舷材には損傷 が見られず施設の性能にかかわる変化は見られない。 こ

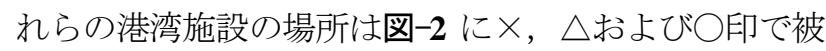
害の程度が分かるように示している.

\section{5. 港内流れと船舶の漂流特性}

図-10 は津波の伝播・浸水計算から得られた地震発生

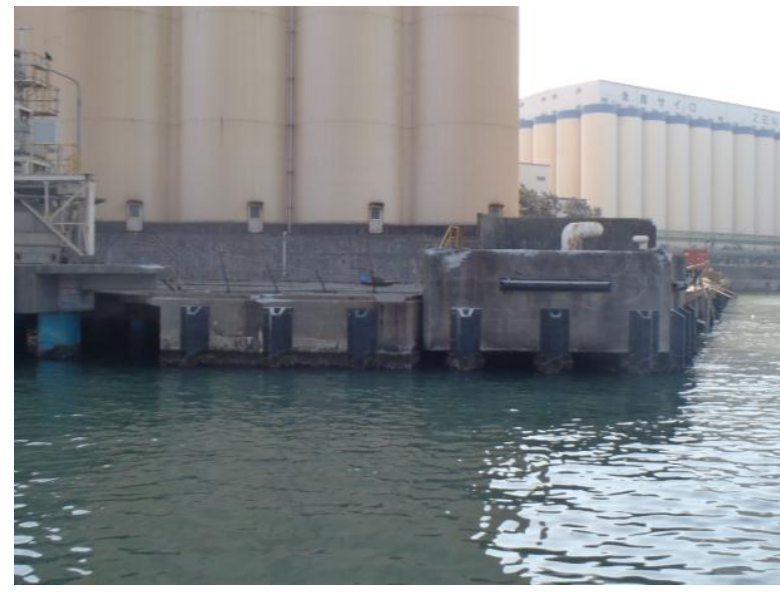

写真-3 岸壁 $(\mathrm{N}-3)$ の衝突被害状況

から3 時間までの最大流速とAIS データの航跡を重ねた ものである. 図中のS1 S3 は3 隻の船舶（それぞれ総卜 ン数106,333 GT，36,008 GT，14,286GTである）の地震発 生時の係留位置を赤色の船形記号で示しており，それら の漂流軌跡を白線で，衝突位置を赤×印で示している.

津波の数值計算には，富田・柿沼》による高潮津波シ ミュレータのうちの静水圧流動モデルSTOC-ML（単 層）を用いた。 基礎方程式は連続式と静水圧近似を適用 したNS 方程式であり，スタッガード格子で空間を離散 化し, leap-frog 法により時間発展させている. 最小領域 の計算格子の大きさは $12 \mathrm{~m}$ である. 津波の初期波形は, 津波の観測波形から逆インバージョンにより，断層破壊 の時間発展を考慮して解析したTakagawa and Tomita ${ }^{8}$ のモ デルを使用した．この津波計算により，北公共埠頭での 浸水深 $1.86 \mathrm{~m}$, 南公共埠頭での浸水深 $2.80 \mathrm{~m}$ は, それぞ れ $1.80 \mathrm{~m}$ と3.23 m で再現された.

数值計算の結果によると, 中央航路から南航路にかけ て流れが速い場所がある一方，港奥部では岸壁からの反 射波があることから最大流速は遅くなっている．地震時 に港奥部に係留されていた船舶 $\mathrm{S} 2$ と船舶 $\mathrm{S} 3$ は, 継続時 間の長い津波であるが流速の大きさに伴って船舶の移動 距離は短かったため港奥部に留まっている。，一方，中央 航路の中ほどに係留されていた船舶S1 は，中央航路を 流れる強い流れにのって移動距離が長かったために，そ の漂流過程において中央航路に突き出た栈橋等に衝突し ている.さらに北航路や南航路にも漂流した. しかし, 船の喫水が $15 \mathrm{~m}$ 程度あるため, それよりも水深の浅い 港奥部に流されることはなかった.

\section{6. おわりに}

本研究は津波来襲時のAIS データを使って津波漂流時 の船舶挙動と港湾施設の衝突被害について分析を実施し, 主に次のことを明らかにした。

(1) 大型船舶が港湾施設に衝突寸るときの最大速度は時 


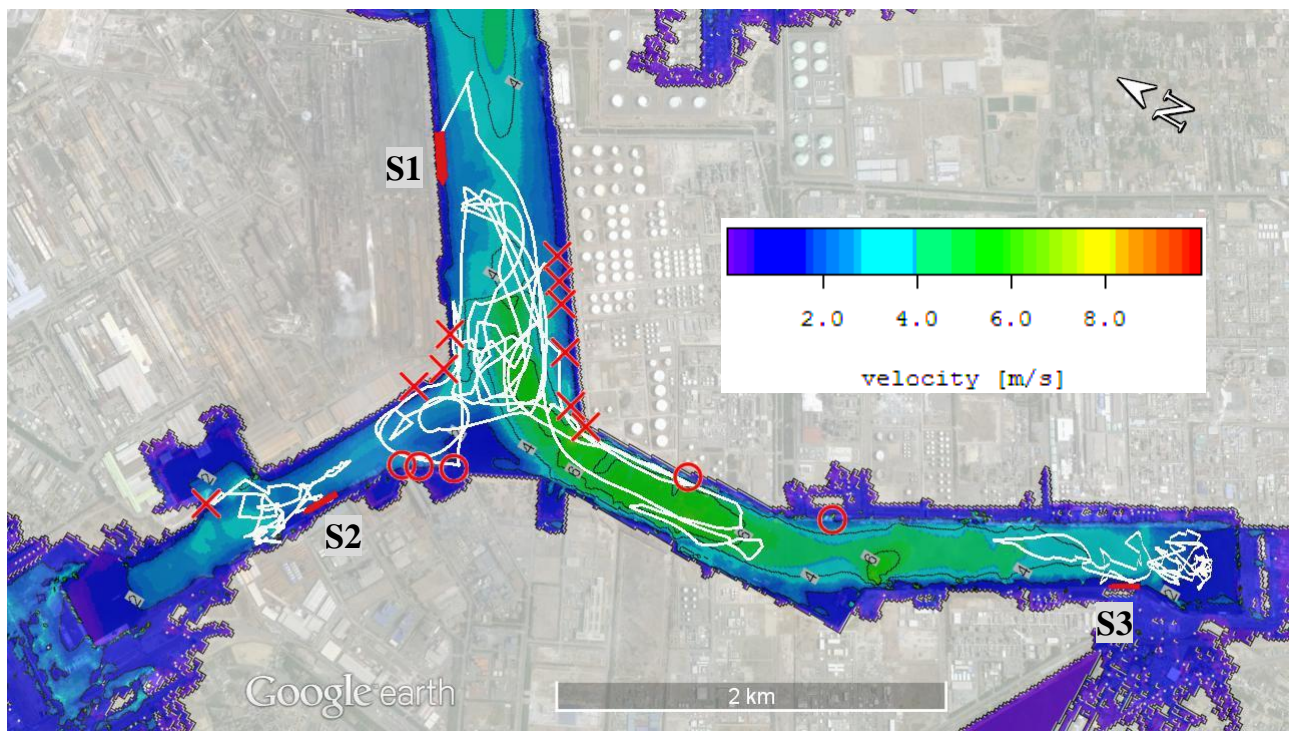

図-10＼cjkstart最大流速と漂流船舶の航跡

間と共に低下寸るが，船舶が大型であるほど衝突被害は 地震発生から長時間経過しても発生する.

(2) 掘り込み港湾の港奥部では, 反射波の影響で津波の 流れが遅くなる.このことが, 継続時間の長い津波であ っても漂流距離を短くし，さらに速い速度で衝突する可 能性を低くするので, 衝突被害の甚大化が軽減される.

(3) 掘り込み港湾のような水路状の港湾であっても, 船 舶の漂流タイプは平行漂流だけでなく, 斜め漂流や横漂 流，さらには回転も発生する.これは，狭い水路であっ ても，津波の押し引きの転換時を含めた津波による流れ の複雑性や操船という人為的要因に起因している. 特に 人為的要因が加わることは，船舶の漂流を予測すること を困難に寸る，一方，船舶における衝突箇所は船首・船 尾が多いことが，鹿島港の事例で明らかになった。

\section{参考文献}

1) 岩井聰, 長沢準, 小田一紀, 庄司邦昭 : 船舶の橋脚 衝突と衝突力, 海岸工学講演会論文集, pp.655-659, Vol. 26, 1979.

2) 上田茂, 大井栄二郎：港湾の係留施設における防衝 工の設計について，港湾技研資料，No.596， 1987.

3) 高橋重雄ら： 2011 年東日本大震災による港湾・海
岸・空港の地震・津波被害に関する調査速報，港湾 空港技術研究所資料，No. 1231，2011.

4) 津金正典：2011 年東北地方太平洋沖地震発生時にお ける海員の地震体感について, 日本航海学会誌 NAVIGATION，第 178 号, pp. 46-52, 2011.

5)松田信彦，富田孝史：鹿島港における津波来襲時の 船舶避難行動分析, 日本船舶海洋工学会講演会論文 集，第 15 号，pp.109-112， 2012.

6) 港湾空港技術研究所編著, 港湾の施設の維持管理技 術マニュアル，沿岸技術研究センター, pp.39-89, 2007.

7) 富田孝史, 柿沼太郎：海水流動の 3 次元性を考慮し た高潮・津波数值シミュレータ STOC の開発と津波 解析一の適用, 港湾空港技術研究所報告, Vol.44, No.2. 2005.

8) Takagawa, T. and T. Tomita: Effects of Rupture Processes in an Inverse Analysis on the Tsunami Source of the 2011 off the Pacific Coast of Tohoku Earthquake, Proceedings of the Twenty-second International Offshore and Polar Engineering Conference, Vol.3, pp. 14-19, 2012.

9) 松田信彦, 富田孝史, 廉 慶善, 高川智博 : AIS デー 夕を用いた大型船舶の津波漂流シミュレーション, 土木学会論文集 B2（海岸工学）, Vol.68, No.2, pp.I_256-I_260, 2012.

(2015.3.18 受付)

\section{AIS DATA ANALYSIS ON SHIPS TRANSPORTED BY THE 2011 TOHOKU TSUNAMI AND DAMAGE TO PORT FACILITIES BY THE SHIPS}

\section{Nobuhiko MATSUDA and Takashi TOMITA}

The AIS (Automatic Identification System) data on ships in Kashima Port was analyzed to investigate movement characteristics of the ships transported by the 2011 Tohoku tsunami and their collision damage to port facilities. The main results are as follows: 1) Bigger ships can cause damage to the facilities many times even if longer time passed from the earthquake occurrence. 2) In the most inner part of the channelshaped port, water particle velocity which could be reduced by the reflected tsunami shortened the length of ship's movement by the tsunami and reduced ship's speed when colliding with a port facility, resulting in reduction of severe collision damage to the facility. 3) Significant drift movement was observed even in a channel-shaped port with oblique, transverse and rotational motions, owing to complex tsunami flow and various ship maneuvering. 